\title{
Pseudartrose etter costafraktur
}
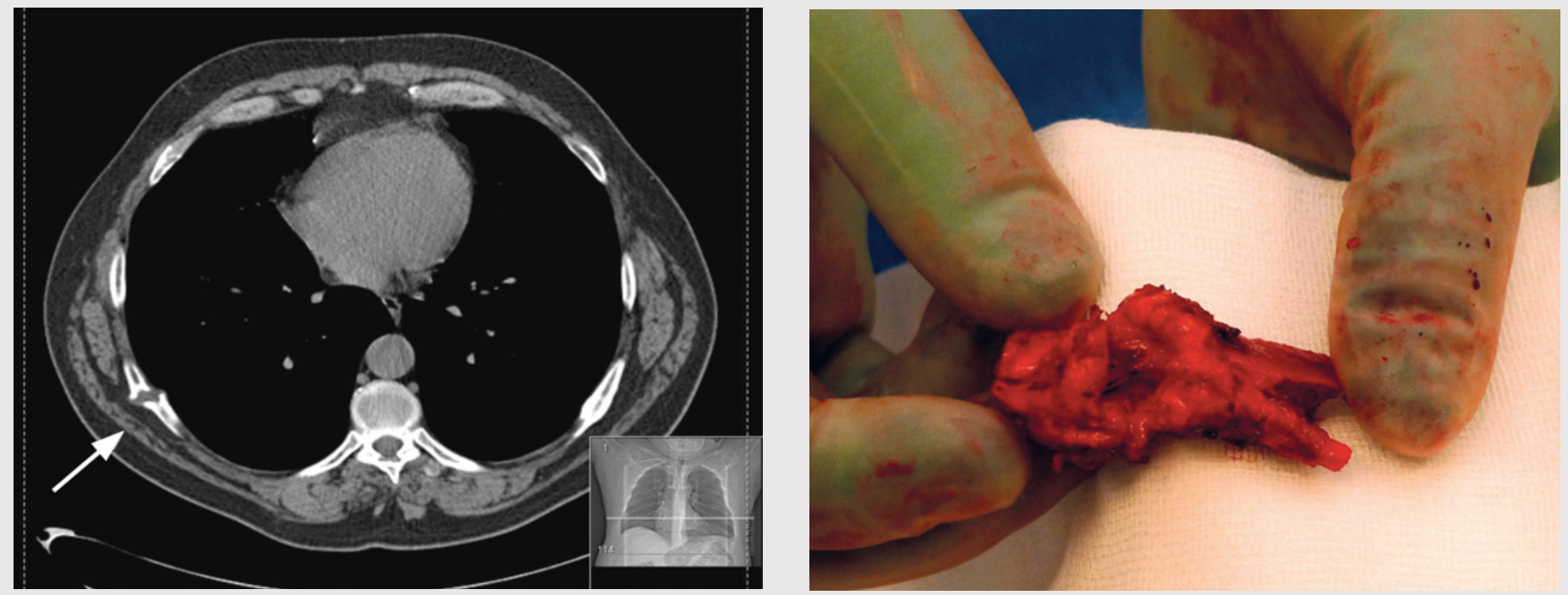

En 56 år gammel mann hadde i flere måneder vært plaget med smerter fra en lokal hevelse i ryggen. Han ble henvist til kirurgisk poliklinikk med spørsmål om tumor. Ved klinisk undersøkelse fant man en $10 \times 10 \mathrm{~cm}$ stor tumor lokalisert på høyre side paravertebralt i torakalnivå. CT viste psedartrose dorsolateralt i 7. costa (bildet til venstre). Man valgte å avvente utviklingen. Han var til flere kontroller uten subjektiv eller røntgenologisk (CT) bedring.

Pga. uutholdelige smerter, selv under behandling med gruppe B- og C-analgetika, ble pasienten henvist til sykehusets smertepoliklinikk. Det ble forsøkt forskjellige medikamentregimer, bl.a. morfinpreparater i høye doser, antidepressiver og antiepileptika. 11 måneder etter første konsultasjon ble han tilbudt operativ behandling. Han hadde på denne tiden gått opp $15 \mathrm{~kg}$ i vekt og beskrev sterkt nedsatt livskvalitet.

Gjennom et lite snitt ble pseudartrosen og tilgrensende friskt bein resecert. Resektatet målte $4 \mathrm{~cm}$ (bildet til høyre). Histologisk undersøkelse viste pseudartrose. Det postoperative forløpet var ukomplisert. Halvannen måned etter operasjon hadde pasienten seponert samtlige analgetika og var smertefri.
Costafraktur er en hyppig skade ved stumpt traume mot thorax. I de aller fleste tilfellene tilheler slik skade spontant under konservativ behandling, og langtidssekvele er uvanlig. Pseudartrose er en sjelden, men kjent komplikasjon.

Operativ behandling av costafraktur anses som kontroversielt, men ved pseudartrose kommer man vanligvis ikke til mål med konservativ behandling. Det er beskrevet forskjellige operative metoder, som beintransplantasjon i kombinasjon med ulike osteosyntesemetoder, eller reseksjon (1). Vår pasient ble operert med reseksjon av pseudartrosen, og det ga et godt resultat. Metoden er enkel og etter vårt syn å foretrekke.

\section{Jørgen B. Vennesland}

joergen.vennesland@hotmail.com

Universitetet i Göttingen

Göttingen

\section{Svein Svenningsen}

Ortopedisk avdeling

\section{Øyvind Vennesland}

Kirurgisk avdeling

Sørlandet sykehus Arendal

Pasienten har gitt samtykke til at artikkelen blir publisert.
Jørgen B. Vennesland (f. 1986) er medisinstudent ved Universitetet i Göttingen.

Forfatter har fylt ut ICMJE-skjemaet og oppgir ingen interessekonflikter.

Svein Svenningsen (f. 1946) er dr.med., spesialist i ortopedi og tidligere avdelingssjef ved Ortopedisk avdeling, Sørlandet sykehus Arendal. Forfatter har fylt ut ICMJE-skjemaet og oppgir ingen interessekonflikter.

Øyvind Vennesland (f. 1950) er spesialist i karkirurgi og avdelingsjef ved Kirurgisk avdeling, Sørlandet sykehus Arendal.

Forfatter har fylt ut ICMJE-skjemaet og oppgir ingen interessekonflikter.

\section{Litteratur}

1. Lafferty PM, Anavian J, Will RE et al. Operative treatment of chest wall injuries: indications, technique, and outcomes. J Bone Joint Surg Am 2011 93: 97-110.

Mottatt 21.9. 2011, første revisjon innsendt 15.1. 2012, godkjent 26.1. 2012. Medisinsk redaktør Petter Gjersvik. 